\title{
The Semantics of Self-Denial: The New American Studies through the Lens of Luhmann's Social Systems Theory ${ }^{1}$
}

\author{
Michael Boyden
}

\section{The New Americanists}

The New Americanists form a rather loose grouping of literary and cultural critics who in different ways oppose the presuppositions of the "Old" American Studies of the Cold War era, as embodied by the writings of Richard Chase, R.W.B. Lewis, Lionel Trilling, Leslie Fiedler, and others. The label "New Americanists" was first applied by Frederick Crews in an article for the New York Review of Books in which he referred to a number of scholars (among them Donald Pease, Jane Tompkins, David Reynolds, Philip Fisher, Walter Benn Michaels, and Myra Jehlen) whose critical practices diverged markedly from and in many respects clashed with those of the previous generation through their joint focus on the ideological implications of American literature. (Crews 68-69) Crews intended the label "New Americanists" pejoratively, as he detected in these authors' insistent questioning of the established canon of great American authors (especially those associated with the so-called "American Renaissance" of the mid-nineteenth century, a term introduced by F.O. Matthiessen in a 1941 study of the same name that counts as one of the master-texts of American Studies) an attempt to displace the old guard and assume a position of power in the academy. ${ }^{2}$ As happens so often with the rise of a new critical school (a term that hardly seems applicable to such a motley group of critics as the New Americanists), the label was internalized and transformed into a badge of pride after

\footnotetext{
${ }^{1}$ Previously published in: Marietta Messmer and Armin Paul Frank, eds. The International Turn in American Studies. Frankfurt/Main and New York: Peter Lang Verlag.

${ }^{2}$ F.O. Matthiessen. American Renaissance: Art and Expression in the Age of Emerson and Whitman. London/New York: Oxford University Press, 1941.
} 
Donald Pease slyly used Crews's critique as his cue to introduce the widely-read 1990 special issue of Boundary 2 devoted to "The New Americanists: Revisionist Interventions into the Canon" (Pease, New Americanists 17,1$){ }^{3}$

If we can discern a silver thread running through the contributions collected in that seminal Boundary 2 issue - it was reprinted four years later as the second volume of Pease's New Americanists book series at Duke University Press but significantly without an explicit reference to the self-assertive identifier "New Americanists" in the title - , it is probably a shared commitment to teasing out the imperial implications of U.S. culture, which heretofore literary scholars had associated predominantly with the genre of the romance and what it evokes. (Pease, Revisionary Interventions) This shift from innocence to guilt, or from a belief in the "Adamic" nature (as in R.W.B. Lewis's 1955 bestseller The American Adam) of American culture to a persistent questioning of its involvement in the spread of U.S. empire, becomes apparent if we compare the New Americanists' dominant concerns to those of a prominent Americanist of the foregoing generation, Robert E. Spiller, who is best known as the editor-in-chief of the monumental Literary History of the United States (1948), a landmark publication that remained practically unrivalled in the field until the publication of Emory Elliot's Columbia Literary History of the United States exactly four decades later. (Spiller, Letter 140) Towards the end of his career, when plans for a new history of American literature were on the table, Spiller looked back on the rise of American Studies as a legitimate struggle against a "lingering colonialism" supposedly ingrained in U.S. culture. (Letter 140) In the Literary History of the United States, Spiller and his team had attempted to overcome this colonial complex by stressing the "cosmopolitan" (as opposed to the narrowly "Anglo-Saxon") roots of American literature and by conceptualizing U.S. culture in terms of a series of waves beating in from the Atlantic but also rolling back to

\footnotetext{
${ }^{3}$ It is interesting to note that the New Americanists appear more as a unified school in Europe than is the case in the United States. This can be explained by the strong institutional link between the Futures of American Studies Institute which Donald Pease directs at Dartmouth on the one hand, and, one of the most distinguished European centers of American Studies on the other, namely the John F. KennedyInstitut in Berlin. Another way of accounting for this optic illusion may have to do with the realization that presenting oneself as more marginal than one really is tends to make one appear more central than one really is.
} 
the Old World. Spiller claimed that American literature had reached its first "literary fulfillment" when Emerson, Thoreau, Hawthorne, Whitman and Melville, the five authors Matthiessen had singled out for discussion in his American Renaissance, began to assert their intellectual independence from Europe.

It is significant to note, given the New Americanists' revisionist agenda, that even a sidelong glance at some of their most outstanding publications reveals a persistent preoccupation with precisely this handful of mid-nineteenth century writers. Donald Pease's Visionary Compacts, David Reynolds's Beneath the American Renaissance, John Carlos Rowe's At Emerson's Tomb, and oft-quoted multiple author collections such as The American Renaissance Reconsidered or Ideology and Classic American Literature direct their critical gaze for the most part, if not exclusively, to the authors canonized in the Spiller history. ${ }^{4}$ Even though Spiller's wave theory of American literature, inspired for a large part by Vernon Louis Parrington's Main Currents in American Thought and The Reinterpretation of American Literature edited by Norman Foerster, has long since fallen into disrepute because of a growing defiance of grand narratives; and even though his evolutionary philosophy has meanwhile been replaced by alternative, in some respects more sophisticated models - the leading New Americanists seem to have a predilection for French intellectuals such as Althusser, Lacan, and Foucault -, the continued investment in "classic" American literature has left Spiller's original design relatively intact and thus testifies to its continuing institutional success. ${ }^{5}$ It is true that a number of formerly neglected or excluded authors have been foregrounded (e.g.

\footnotetext{
${ }^{4}$ Donald E. Pease. Visionary Compacts: American Renaissance Writings in Cultural Context. Madison: University of Wisconsin Press, 1987; David S. Reynolds. Beneath the American Renaissance: The Subversive Imagination in the Age of Emerson and Melville. New York: Alfred A. Knopf, 1988; John Carlos Rowe. At Emerson's Tomb: The Politics of Classic American Literature. New York: Columbia University Press, 1997; Walter Benn Michaels and Donald E. Pease, eds. The American Renaissance Reconsidered: Selected Papers from the English Institute, 1982-1983. Baltimore: Johns Hopkins University Press, 1985; Sacvan Bercovitch and Myra Jehlen, eds. Ideology and Classic American Literature. Cambridge: Cambridge University Press, 1985.

${ }^{5}$ Vernon L. Parrington, Main Currents in American Thought. 3 Vols. New York: Harcourt, Brace \& World, 1927-30; Norman Foerster, ed. The Reinterpretation of American Literature: Some Contributions toward the Understanding of Its Historical Development. New York: Harcourt, Brace \& World, 1928.
} 
Frederick Douglass or Margaret Fuller), but the main difference between the New and the Old Americanists does not principally lie in the kind of authors that receive discussion but rather in the way their centrality is highlighted or asserted. ${ }^{6}$

In his introduction to American Renaissance, Matthiessen famously asserted that his main reason for grouping together Emerson, Thoreau, Hawthorne, Melville, and Whitman, despite their obvious differences in terms of temperament and philosophy, had been these authors' shared "devotion to the possibilities of democracy" (Matthiessen, American Renaissance ix). Spillers's Literary History of the United States almost literally reproduces Matthiessen's rationale when stating that all five authors address, however different the results, "the central goal and problem of democracy" (Spiller, Literary History 353). This assumption, fed to generations of American literature students, that the great American authors somehow embody the democratic principles of the American nation and its people, appeared as a dangerous incommensurability to the New Americanists, most of whom received their education in the 1960s and 1970s when the foundations of American democracy were increasingly called into question by the democratization of higher education, the Civil Rights movement and the protests against the Vietnam war. The New Americanists no longer envision the rise of American literature in terms of a continuing struggle against (English, and, by extension, European) colonialism, but rather in terms of the imperial violence inflicted by the U.S. as an emergent neo-colonial world power on the rest of the world.

While for Spiller and company mid-nineteenth century U.S. culture was associated with the growth of personal liberties and freedom, the New Americanists have reinterpreted that culture, often with interesting results, in light of Jackson's Indian Removal policy, the "peculiar institution" of slavery, nativist hysteria against immigrants and Catholics, or Polk's expansionist war against Mexico. This is particularly evident in Emerson criticism, where the standardbearer of Transcendentalism has been transformed from a leading spokesperson of democratic liberalism into a much more complex but

\footnotetext{
${ }^{6}$ Significantly, Emory Elliot's Columbia Literary History of the United States, which was profiled explicitly as a reaction against the Spiller history and the kind of master narrative it conveys, leaves Matthiessen's original grouping intact in a section straightforwardly entitled "American Renaissance".
} 
also more dubious persona whose writings reflect or, according to some critics, even justify the ideological workings of imperialism. To give just one example, in his book The Emerson Effect Christopher Newfield argues that in his well-known essay "Self-Reliance" Emerson did not, as a long line of eminent Emerson critics suggests, embrace individualism and democracy but rather "consistently repudiated both at the same time" (Newfield 22). A similar reframing is noticeable in scholarship on other canonical authors as well. The central opposition between American democracy and European-style aristocracy, which for many decades structured critical debates on classic American literature, therefore seems to have been replaced by another guiding distinction, namely that between submission or resistance to Euro-American imperialism.

It is beyond the scope of this chapter to evaluate the adequacy or inadequacy of this remarkable interpretative shift of American culture. What I hope to do, rather, is to show how this apparent inversion of values has taken shape. Niklas Luhmann's social systems theory offers a sufficiently complex and worked-out framework for tracing this paradoxical dynamic. What bears remarking, from such a Luhmannian perspective, is not so much that the established literary canon and the dominant interpretations of it, as the New Americanists claim, should be revised because they would embody sexist, classist, racist and other values considered oppressive; the thing to note when it comes to the institutional logic of American Studies, is rather that this institution can continue to exist at all given all the above objections. Indeed, as indicated above, what is surprising is that, in spite of all the criticisms leveled against the authors sanctified by Matthiessen and Spiller, their writings have remained largely unchallenged at the center of the American canon. What is of interest, therefore, is not so much the supposed paradigm shift from selfassertion to self-criticism, a conflict often dramatized as a form of patricide by "Old" and "New" Americanists alike, as the disciplinary dynamic of self-assertion through self-criticism. This dynamic, as I will argue, is by no means peculiar to the New Americanists but has characterized the field of American Studies from the beginning.

\section{Social Systems and the Functionalist Tradition}

The relative neglect in American universities of Niklas Luhmann's social systems theory, which in Europe and elsewhere is commonly 
regarded as one of the most ambitious attempts of the late twentieth century at grounding modern society in a comprehensive intellectual design, has been explained in terms of its high level of abstraction, often consciously fostered by Luhmann through his predilection for relatively obscure thinkers such as the mathematician George Spencer Brown, along with the translation problems involved in conveying the subtle ironies of Luhmann's disengaged writing style. In the introductory note to the English-language edition of his principal work Soziale Systeme, which appeared more than a decade after the publication of the German original, Luhmann himself admitted rather dryly that what he had written was "not an easy book". (Luhmann, Social Systems xxxvii) ${ }^{7}$ Characteristically, instead of mitigating this problem, Luhmann's "Instead of a Preface" withholds from the reader any personal information on how he came to write the book, but instead elaborates on his systematic exclusion of the "subject" (or what Luhmann calls psychic systems) from the realm of the social. Yet, the willful complexity of Luhmann's theory alone does not suffice to account for the reluctant reception of his work in the United States, all the more so because other major thinkers have of late found their way into the American humanities in spite of such obstacles (note, for instance, Hegel's remarkable resurgence in postcolonial studies).

What, in my opinion, makes Luhmann's social systems theory particularly challenging in the American context is its reconciliation of an old-fashioned belief in a supertheory that would explain everything with a concomitant realization of the impossibility of a credible outside position, a Cartesian vantage point from which society can be observed. The complexity of Luhmann's theory architecture derives in large part from what he (following Spencer Brown) would call the "unfolding" of this contradiction between the construction of a supertheory and the apparent unavailability of an objective point of view for doing so. Unlike contemporary philosophy, which sees this necessary but impossible project as part of the postmodern predicament, Luhmann has made original use of insights from cybernetics and evolutionary biology to develop a self-referential theory which conceptualizes modern society as a horizontally ordered concatenation of subsystems, each of which can make universalist

\footnotetext{
${ }^{7}$ Soziale Systeme: Grundriß einer allgemeinen Theorie was published in 1984 by Suhrkampf in Frankfurt am Main.
} 
claims within its own realm but none of which can impose such claims onto other functional domains. Thus, even while it aspires to explain all of society, social systems theory belongs to the subsystem of science, which means that the rest of society can function quite well without it, a conclusion which Luhmann lards with masterful selfirony.

It is not hard to see why such a perspective should generate resistance among American scholars, who are generally more receptive to immediate social concerns than their European counterparts. On the one hand, Luhmann's taste for high theory and his attempt to position himself in relation to an "Old" European philosophical tradition squares badly with the postmodern defiance of grand narratives which permeates the U.S. academic world. This defiance also characterizes the New Americanists, whose critique of the myth and symbol school, for instance, derives its momentum largely from their refusal to summarize "America" in terms of a couple of unifying ideas (such as innocence), which for them indirectly serve to explain away deeper inequalities (the not so innocent treatment of minorities under the banner of freedom). On the other hand, Luhmann's anti-essentialist design seems to go against what the New Americanists would label a "counterhegemonic" discourse, a counternarrative through which they hope to effectuate social change. Luhmann's theory does not deny such forms of agency, but his systematic theorization of the self-implicative logic of society, a logic from which, as we noted, not even his own theory of society is exempt, implies that the revisionism of the New Americanists can only acquire meaning in relation to, by enveloping it within, the society against which it reacts.

From the perspective of the New Americanists, Luhmann's systems theory thus seems at once dangerously overambitious and not ambitious enough, which may at least in part indicate why it has hardly percolated in American theory debates. But, in line with Luhmann's cybernetically-inspired language, such "limited connectivity" may at the same time contain the promise of communicative acceptance. I want to stress from the beginning, though, that by applying Luhmann's systems theory to the New Americanists I do not mean to deny the legitimacy of their oppositionalism by suggesting that they would be somehow less radical than they claim to be. On the contrary, I hope to analyze this radical revisionism as an indispensable operational feature of modern 
society. I want to approach this by resituating social systems theory in the familiar tradition of functionalism from which it emerged. Most Luhmann textbooks transmit his ideas rather dogmatically, thus naturalizing concepts and models that were meant to provoke new ways of approaching social theory. Pointing attention to systems theory's connection to functionalism, a tradition well-known in the American social sciences, can make his theory more tangible even while indicating where it goes beyond some of the more problematic assumptions of traditional functionalism.

A functionalist argument is normally regarded as a special type of causal explanation, whereby the consequences of an institutional or behavioral pattern indirectly serve to explain it. A wellknown example is that of a rain dance promoting group solidarity. While the dance ostensibly functions to appease the gods, its hidden function is to reinforce the tribal hierarchy. A valid functional argument thus needs to conform to two basic conditions. First, there has to be a degree of circularity. The ritual dance is indirectly sustained by its effects, i.e. the maintenance of peace in the tribe, which results in a reverse causal loop that keeps such traditions alive. What further sets functional reasoning off from other types of consequence explanations, such as those invoking individual aims, is the condition of latency. According to this criterion, a rain dance can only fulfill its solidarity-enhancing function if those performing it do so without realizing what it is really about. As the argument goes, if the dancers would find out that by performing such a ritual they were unwittingly strengthening the social order, the idiosyncrasy of individual intentions would start competing with the common good of maintaining solidarity.

I have deliberately used a relatively simple example from early anthropology to bring out some of the problems involved in the functionalist paradigm, most of which have to do with its speculative or anti-empirical slant. After all, how can we ascertain whether a rain dance really serves the purpose that the ethnologist assigns to it? Why should such a ritual help to preserve the group (why, for instance, could it not do the exact opposite)? Perhaps we simply impute this function to the group assuming that what is, is right? And, even if it can be ascertained that there is indeed a reverse causal mechanism working underneath the surface, it still remains to be seen to what extent this feedback mechanism is indeed produced unintentionally and whether it really remains unrecognized. Such functional reasoning 
thus adopts the kind of Cartesian viewpoint that according to postmodern thinkers can no longer be maintained. The emphasis on group stability as the ultimate functional requisite of clan society can be identified as an ideological ploy that denies its members any right to agency. This is a familiar charge leveled against Alfred RadcliffeBrown's notion of the "ritual attitude" on which primitive cultures would depend for their survival. ${ }^{8}$

Although functionalist theory has become much more sophisticated since the days of Radcliffe-Brown, most of the problems (both real and imagined) associated with it have not gone away. In the 1960s, for instance, Talcott Parsons's structural functionalism, which had dominated sociological theorizing for about two decades, came under heavy attack from C. Wright Mills and others on the assumption that, through its emphasis on system maintenance and equilibrium, the notorious Parsonian four-function model sanctioned rather than analyzed the established order at a time when the United States was assuming absolute world power. ${ }^{9}$ During the 1980s and 1990s, attempts have been made to rehabilitate Parsons by opening up his rather top-heavy theoretical framework to social change. This "neofunctionalist" turn, which has been relatively short-lived, can equally be interpreted in light of the persistent charge of conservatism. (Alexander, Neofunctionalism) ${ }^{10}$ In Germany, the Parsonian legacy has been kept alive thanks to Luhmann and Jürgen Habermas, both of whom have drawn extensively on structural functionalism. The label, however, has retained very negative connotations, as appears from the well-known Luhmann-Habermas debate in the early 1970s, whereby the latter accused the former of being a functionalist. ${ }^{11}$

However, Luhmann's 1984 masterpiece Soziale Systeme

\footnotetext{
${ }^{8}$ Alfred R. Radcliffe-Brown. Structure and Function in Primitive Society. New York: The Free Press, 1965.

${ }^{9}$ Parsons distinguished four functional requisites or imperatives necessary for system maintenance: adaptation, goal attainment, integration, and latency. Together, these have become known as the AGIL scheme, which Parsons then further refined and differentiated to analyze diverse social phenomena. Parsons's model was criticized by C. Wright Mills in The Sociological Imagination. New York: Oxford University Press, 1959.

${ }^{10}$ Meanwhile, Alexander has already declared the end of this return to Parsons. See Neofunctionalism and After. Malden, MA: Blackwell, 1998.

11 Jürgen Habermas and Niklas Luhmann. Theorie der Gesellschaft oder Sozialtechnologie: Was leistet die Systemforschung? Frankfurt am Main: Suhrkamp, 1971.
} 
revealed that his brand of systems theory, even if it remains strongly indebted to Parsons's structural functionalism, at the same time departs from it in significant ways. ${ }^{12}$ The first thing to note is that Luhmann shifts emphasis away from the maintenance of stability to the management of complexity. How, Luhmann asks, does modern society deal with the problem of (ever growing) complexity? ${ }^{13}$ Controlling it from the top down seems futile. Instead of imposing a system of unilateral control, Luhmann argues that modern societies have developed sophisticated ways of channeling complexity through strategies of selection, differentiation and temporalization. That means, very simply, that complexity is countered by internalizing it, or by reproducing it on another level. The result is a state of "dynamic stability," whereby the social system exerts control in paradoxical fashion by anticipating, as it were by inviting, its eventual contestation (Luhmann, Social Systems 49). This shift from stability to dynamic stability, or from continuity to contingency, presents a major step forward in relation those approaches which regarded class stratification as a "natural" fact of society. ${ }^{14}$

What does all of this entail for functional methodology? Above, we defined functional arguments as special forms of causal argument, whereby the end (the hidden function) justifies the means (the item to be explained). The problem with this means/end logic of traditional functionalism was that it could never fully answer the question as to what it is, in the end, that justifies the end that justifies the means. Does the item become dysfunctional if it reaches its goal (stabilizing the group)? In response to such obstacles, Luhmann

\footnotetext{
${ }^{12}$ Luhmann's status as a highly innovative thinker became even more apparent in 1997 after the appearance of the two-volume Die Gesellschaft der Gesellschaft (Suhrkamp), which remains as yet untranslated in the English language.

${ }^{13}$ The main focus of Luhmann's systems theory is modern society, which he relates to the emergence of self-referential function systems (such as the economy, law, art, and so on) on the one hand and the development of distribution media (such as writing and print) on the other hand. Luhmann argues that these structural conditions, which started to manifest themselves in their full force around the eighteenth century, have not undergone such fundamental changes in recent times as to warrant the use of the label "postmodern".

${ }^{14}$ For the functional theory of stratification, see Kingsley Davis and Wilbert Moore. "Some Principles of Stratification." American Sociological Review 10 (1945): 242-49. I should add that by saying that stratification is not a functional necessity of modern society, Luhmann does not therefore assume that it does not exist. But it is no longer the primary form of differentiation.
} 
adopts an anti-teleological approach, which envisions only one end, namely the end of the social as such, which is probably the only end which everybody would want to avoid. From this perspective, the aim of functional analysis is no longer merely to discover causalities, but above all to compare different but functionally equivalent solutions to the problem of society (which obviously only becomes a problem because there is not just one, ready-made solution). Put differently, the explanatory value of functional arguments no longer resides primarily in uncovering a kind of invisible hand pulling the strings of society, but rather in examining how society puts forward specific answers (which are equivalent, since all of them come from within society, which also means that all of them can in principle be replaced) to the question of its existence. The attention thus shifts from the determination of functions to the process of function attribution. In other words, causal arguments become subtypes of functional ones instead of the other way around.

This shift from causalities to equivalences also leads us to redefine the condition of latency. One recurring problem in traditional functionalism was that the researcher can never really know for sure that society does not really know what it is not supposed to know. Luhmann addresses this issue by consigning psychic systems to the "environment" of the social, a drastic theoretical move that has often been misunderstood as a form of anti-individualism (it is, in fact, the exact opposite). In social systems theory, latency therefore no longer just refers to a lack of awareness on the part of individuals, but rather entails a lack of themes to push forward communication (Social Systems 335). ${ }^{15}$ In every society, there are things that cannot be communicated because they affect the very structure of that society. Each society thus creates its own latency needs. A hierarchical order will protect itself through counter-discourses that help it to let off steam but that do not, in general, constitute an alternative to that order (carnivals cannot last forever). In modern society, by contrast, alternatives are already abundantly present. As a matter of fact, its legitimacy depends on its capacity for offering equivalent solutions,

\footnotetext{
${ }^{15}$ The elementary building block of society, for Luhmann, is communication. This is another major departure from Parsons, who based his theory on actions and their functional components. The communicative approach, at least on the level of theory, has the advantage of steering free from the thorny problem of intentionality. Whereas actions necessarily presuppose an ulterior design, communication can very well babble on without it.
} 
for stimulating criticism. Put differently, all those things that pose a threat to a hierarchy constitute a condition of possibility for a horizontally structured society. What needs to be kept latent, in such a context, is not what keeps individuals from speaking out against domination but rather the selectivity of public opinion as such.

The overall criticism directed against functionalism was that it largely ignored conflict and change. Even if these factors were recognized, they were often approached as "dysfunctional" for the equilibrium of the sociopolitical order. Social systems theory, by contrast, explicitly highlights the importance, even the productive potential, of paradoxes and contradictions in the formation and maintenance of modern society. The complexity of Luhmann's prose style, so disconcerting and irritating to the uninitiated reader, thus needs to be understood in terms of his attempt to create a theoretical framework commensurate with the exigencies of an increasingly complex world society, which operates precisely on the basis of perpetual internal unrest. According to Luhmann, modern society constitutes a "self-substitutive order" (Social Systems 409). Simply put, this means that the social system protects itself against annihilation by including its own negation as a condition of possibility, by inviting its own replacement, which results in a remarkably high tolerance for uncertainty. The problem for such a self-substitutive order is no longer how to control dissent but how to exploit it, given that there are so many options available, all of them apparently equally valid.

Conceptualizing modern society as a self-substitutive order has far-reaching implications for the role of the critic in it, which is where my discussion of systems theory reconnects to that of the New Americanists. The problematization of latency in the modern world signifies that virtually everything can become the object of critical scrutiny. The one thing that has to remain latent, in such a context, is the very bankruptcy of the idea that there are certain things that cannot be communicated. In a functionally differentiated order, such latencies (for instance, the mystery of the afterlife) can no longer self-evidently block critical inquiry since this would offend the premises of structural selection. This dehierarchization of the social, however, comes at the price of the decreasing social relevance of criticism. In a somewhat sardonic turn, Luhmann states that the modern critic becomes "radical in a peculiarly hopeless fashion" (Social Systems 342). The authority of the critic no longer depends primarily on 
uncovering latent truths, because such mechanisms of manifestation are already built into modern society's operational structure. All that is left for the critic to do, it seems, is anticipate such self-falsificatory gestures by communicating his ignorance.

\section{American Studies as a Self-Substitutive Order}

The prominent European Americanist Winfried Fluck has described the revisionist program of the New Americanists in terms of a larger predicament of the humanities, which he relates to the professionalization of criticism and more broadly to the "cultural radicalism" ingrained in postmodern society. This radicalism, for Fluck, is the cause of the current plight of the humanities, for it means that professional advancement is only possible by negating or reinterpreting the claims of other critics, which therefore results in a hopeless fragmentation of meaning as every truth claim immediately gets absorbed or aborted by an institutional matrix geared toward dissent. Fluck identifies the New Americanist paradigm as a prominent instance of numerous attempts to overcome this fragmentation, all of which however unwittingly stir up the disease they set out to cure. In order to accomplish their revisionist goals, Fluck argues, these radical critics cannot but reproduce the operational structure that undergirds the humanities in the age of "expressive individualism," which constantly disqualifies or de-futurizes the theories that are produced to understand its deeper meaning. Every critic is therefore doomed to "out-radicalize" his fellow-critics, thus constantly deferring final meanings and values (217).

In this regard, it seems ironic that Fluck's compelling analysis of the New Americanists' revisionism appeared in Pease and Wiegman's The Futures of American Studies, a volume in the New Americanist Duke series, which makes one wonder whether and to what degree Fluck's diagnosis does not itself fall victim to the "paradoxical professional logic" that he identifies as the source of the current crisis in the humanities (211). Fluck takes care, however, to set his critique apart from that of, on the one hand, conservative critics who deplore the loss of the traditional canon and values (an impulse that Gerald Graff has identified as a peculiarly prevalent "humanist myth" in literary studies, by which he means the mistaken idea of a founding consensus), and, on the other hand, Neo-Marxist critics who 
remain stuck in inadequate models of class analysis. ${ }^{16}$ As Fluck indicates, assuming that the radicalization of criticism can be attributed to class differences or market factors results in a "crude sociologist bias," which he observes in the Bourdieu-inspired approach of John Guillory (224). Such an economic analysis, Fluck argues, does not solve the problem of escalating radicalism for it assigns political significance to a development which is in fact a consequence of a cultural development toward ever increasing dehierarchization and individuation.

What Fluck fails to mention in his article is that there is in fact a worked-out theoretical apparatus in place that addresses these issues and avoids such problematic (at once too specific and too vague) terms as "individualism," "professionalism," or "culture". By restricting his argument to the post-World War II period, and by rather intuitively positioning the U.S. academic world against that of Europe, Fluck neglects some of the larger issues involved, such as the operational autonomization of function systems apart from the economy or science, the explosive growth of these systems beyond the reach of the nation-state and its limited instruments for policing the social, and the development of worldwide distribution media. Moreover, his far from neutral rhetoric when describing the American critic's move away from enlightenment values to a meaningless "white-collar race for distinction" betrays that his stance is perhaps closer to the conservative side of the debate, which pretends to counter the defects of professionalization through unspecified cure-all "returns to culture," than he is ready to admit (214). ${ }^{17}$ Rather than pursuing this critique, however, I would like to contribute constructively to the debate by showing how social systems theory can amplify and strengthen Fluck's evaluation of the New Americanists. Luhmann's approach, which I have presented in rather too condensed fashion, can offer a highly reflexive, "polycontextural" (as opposed to a monocausal) framework for redescribing the New Americanists' revisionism in terms of the functional toppling of society in modernity.

To drive home my point of view, I want to concretize things

\footnotetext{
${ }^{16}$ Gerald Graff, Professing Literature: An Institutional History. Chicago: Chicago University Press, 1987.

17 The phrase "return to culture" is taken from Edward Said's Culture and Imperialism. London: Vintage, 1994. xiii-iv.
} 
somewhat by focusing attention on what I consider to be a conspicuous but at the same time fairly representative instance of the New Americanists' counterhegemonic project. In his 2000 book Literary Culture and U.S. Imperialism, John Carlos Rowe, a professor of English at UCIrvine and a self-described spokesperson of the New American Studies, offers a broad-ranging interpretation of the ways in which American writers roughly between the late $18^{\text {th }}$ up to the mid$20^{\text {th }}$ century have been implicated in U.S. imperialism, both on the American mainland and elsewhere. ${ }^{18}$ Following the lead of postcolonial thinkers such as Edward Said, Rowe reinterprets a number of established and less established American literary texts, from Charles Brockden Brown's Wieland to Zora Neale Hurston's Tell My Horse, in view of their complex relation to U.S. (neo-)colonialism during a period that was up until recently seldom associated with such ideological forces. ${ }^{19}$ Rowe's project, therefore, is designed to make manifest the ways in which the selected works have been put to the service of, but have also reacted against, the burgeoning imperial ambitions of the young American nation.

My concern is not with the quality of Rowe's textual analyses, which are on the whole admirably executed and yield compelling insights. Rather, I am interested in the reasons as to why his book should center almost exclusively on what Fluck describes as the "possibility or impossibility of opposition" (217). The main objective of Literary Culture and U.S. Imperialism, Rowe states, is "to learn how to tell the difference between literary practices that serve or challenge the dominant ideology while recognizing how all cultural acts remain to some degree captives of their historical and thus ideological situations" (79). "[O]ur best teachers" as Rowe phrases it, are those authors (Melville, Twain, Du Bois as opposed to Brown, Poe, or Henry James, with a number of ambivalent cases in between) who recognize at once the need and the danger of opposing American hegemony and therefore knowingly anticipate their apparently inevitable incorporation into the ideological machinery of U.S. exceptionalism. For instance, Rowe states that Typee poses the first real "resistance" to American neocolonialism because Melville, unlike

\footnotetext{
18 John Carlos Rowe, Literary Culture and U.S. Imperialism. Oxford: Oxford University Press, 2000.

${ }^{19}$ In the preface, Rowe describes his book as a prelude to another study dealing with the cultural implications of U.S. foreign policies in Southeast Asia around the time of the Vietnam War. To date, this study has not yet appeared.
} 
others, "recognizes the difficulty of combating forms of cultural imperialism at home and abroad that rely on the very rhetorical powers that are the resources of the imaginative writer" (17). Twain's vigorous anti-imperialism, by contrast, would have instilled in him a belief in universal democracy through which he "unwittingly anticipat[ed]" American neo-imperalist practices that use such democratic ideals to justify territorial expansion (18).

Rowe takes pains to differentiate his approach from that of deconstructionist and other textual critics, whom he blames for failing to take into account variables such as sexuality, gender, race, and class in the production of culture. Arguing that we are bound to make judgments no matter what, Rowe does not hesitate to issue bold claims regarding the involvement of certain authors in the American imperial project, or even to extend the history of that project into the colonial period, as when he argues that the modern reader "must recognize the secret complicity" between Brown's gothic romances and the genocides perpetrated by the British on Native Americans during the French and Indian Wars (39). Even while his natural addressee remains the American nation ("our best teachers"), Rowe spreads the burden of U.S. imperial violence over three centuries of European presence in the Americas. The problem with such sweeping arguments is that it becomes very difficult to ascertain whether the critic does not project his own concerns onto the object of study. Is it really true that Brown's fiction "helps distort and disguise" colonial massacres (28)? Or, why, alternatively, should it be that Du Bois "comes closest ... to understanding U.S. imperialism" (196)?

One could venture that Rowe's book is guided by what the political philosopher Philippe Van Parijs at a certain point identified as the "principle of suspicion" inherent in traditional functionalism, meaning a tendency to consistently read certain phenomena symptomatically in terms of their hidden meanings (Van Parijs 129). The problem with this principle of suspicion is that, in the end, it tends to become itself highly susceptible to suspicion. The critic is faulted, not so much for having poked at power structures that were supposed to remain hidden, but for not having done enough to point out what to 
other critics seems manifest. ${ }^{20}$ The quasi-universalization of the principle of suspicion thus presupposes a concomitant expansion of an underlying semantics of ignorance. ${ }^{21}$ In his Observations on Modernity, Luhmann defined the modern expert as "someone who, when asked questions he cannot answer, can be led back to a mode of uncertainty" (70). By this, Luhmann means that, in modern society, a critical judgment can only find acceptance when it can (at least in principle) be contested, revised, or negated, in other words when it is improbable. It is this communicative deficit or ingrown uncertainty at the core of the critical enterprise that drives it forward and ultimately legitimizes it.

I claim that Rowe fails to capture this self-substitutive dynamic because of his emphasis on creating a counterdiscourse to American imperialism. Note, for instance, how he describes the role of criticism in his chapter on Henry Adams:

The ideological means by which a society refuses to accept responsibility for dominating and exploiting others must always be central to our cultural criticism, insofar as the ultimate aim of such criticism is an understanding that brings about social change. (166)

In a context where change is not so much an obstacle to but a constitutive requirement, merely calling for change (yes we can!) does not therefore upset the established order, which establishes itself precisely through its continual replacement. This is not to say that anything goes or to trivialize concerted efforts at reducing inequalities, but rather to point attention to the fact that in a complex world society structural conditions prevail that can mobilize enormous amounts of resistance without disintegrating. Greater "understanding" does not help here because there is no vested interest in keeping things hidden, or, rather, things are kept hidden through the demand for greater

\footnotetext{
${ }^{20}$ Indeed, as it appears, Rowe is by no means immune from his own anti-imperialist critique. In his article "Imperial Literary Culture," Paul Giles wonders whether Rowe's argument "might not in itself constitute a more emollient form of American cultural imperialism." (137)

${ }^{21}$ By a semantics of ignorance I do not mean a lack of knowledge on the part of the scholar but rather a lack of communicative themes that indirectly urges on communication. In this sense, ignorance (or what Luhmann calls communicative latency) constitutes a necessary condition for an institution to establish itself. If we could completely unravel what the great works of American literature are all about, we would have to close the books and take up another profession.
} 
openness. Rowe surely comprehends this paradox but, in his insistence on the all-pervasiveness of U.S. power, he fails to grasp its deeper implications for modern society as a whole.

It is remarkable that, in the above quote, Rowe rather negligently juxtaposes terms like "our" and "others," terms that he promises to question by showing how they are constructed through literary culture. Social systems theory can lift Rowe's approach to a higher level of reflexivity by redescribing such counterconcepts ("America" versus the rest) as part of the self-referential semantics through which a social system emerges and reconstructs itself. Rather than once more "out-radicalizing" existing position-takings, I want to stress what connects the "New" and the "Old" Americanists. Where the so-called old guard reacted against the "Anglocentrism" of earlier critics such as Barrett Wendell and Charles F. Richardson, the socalled "postnational" critics of today oppose the "Eurocentrism" or even "Americocentrism" of the earlier generations. What has remained intact in spite of these "paradigm dramas," as Donald Pease would call them, is the self-corrective incentive structure at the basis of American Studies as a field, which has from the beginning defined itself ex negativo by opposing earlier versions of itself, like a snake sloughing off its old skins. Before we cast off the "New Americanists" in favor of yet another renaissance, therefore, there may be some value in focusing more attention on the societal conditions that produce such disciplinary reversals to begin with. Reading Luhmann would be a good start. 


\section{Works Cited}

Alexander, Jeffrey C. Neofunctionalism. Beverly Hills: Sage, 1985.

---. Neofunctionalism and After. Malden, MA: Blackwell, 1998.

Bercovitch, Sacvan and Jehlen, Myra, eds. Ideology and Classic American Literature. Cambridge: Cambridge University Press, 1985.

Boyden, Michael. Predicting the Past: The Paradoxes of American Literary History. Leuven: Leuven University Press, 2009.

Crews, Frederick. "Whose American Renaissance?" New York Review of Books 35.16 (October 27, 1988): 68-81.

Davis, Kingsley and Moore, Wilbert. "Some Principles of Stratification." American Sociological Review 10 (1945): 242-49.

Elliot, Emory, gen. ed. Columbia Literary History of the United States. New York: Columbia University Press, 1988.

Fluck, Winfried. "The Humanities in the Age of Expressive Individualism and Cultural Radicalism." The Futures of American Studies. Ed. Donald E. Pease and Robyn Wiegman. Durham, NC: Duke University Press, 2002. 211-230.

Foerster, Norman, ed. The Reinterpretation of American Literature: Some Contributions toward the Understanding of Its Historical Development. New York: Harcourt, Brace \& World, 1928.

Giles, Paul. "Imperial Literary Culture.” Novel: A Forum on Fiction 35.1 (2001): 136138.

Graff, Gerald. Professing Literature: An Institutional History. Chicago: Chicago University Press, 1987.

Habermas, Jürgen and Niklas Luhmann. Theorie der Gesellschaft oder Sozialtechnologie: Was leistet die Systemforschung? Frankfurt/Main: Suhrkamp, 1971.

Lewis, R. W. B. The American Adam: Innocence, Tragedy, and Tradition in the Nineteenth Century. Chicago: University of Chicago Press, 1955.

Luhmann, Niklas. Social Systems. Transl. John Bednarz, Jr. with Dirk Baecker. Stanford University Press, 1995.

---. Die Gesellschaft der Gesellschaft. Frankfurt/Main: Suhrkamp, 1997.

---. Observations on Modernity. Transl. William Whobrey. Stanford: Stanford University Press, 1998.

Matthiessen, F. O. American Renaissance: Art and Expression in the Age of Emerson and Whitman. Oxford: Oxford University Press, 1941.

Michaels, Walter Benn and Donald E. Pease, eds. The American Renaissance Reconsidered: Selected Papers from the English Institute, 1982-1983. Baltimore: Johns Hopkins University Press, 1985.

Mills, C. Wright. The Sociological Imagination. New York: Oxford University Press, 1959.

Newfield, Christopher. The Emerson Effect: Individualism and Submission in America. Chicago: University of Chicago Press, 1996.

Parrington, Vernon L. Main Currents in American Thought. 3 Vols. New York: Harcourt, Brace \& World, 1927-30.

Pease, Donald E. Visionary Compacts: American Renaissance Writings in Cultural Context. Madison: University of Wisconsin Press, 1987. 
Pease, Donald E., ed. The New Americanists: Revisionary Interventions in the Americanist Canon. Boundary 2. 17.1 (1990).

---. Revisionary Interventions in the Americanist Canon. Durham, NC: Duke University Press, 1994.

Radcliffe-Brown, Alfred R. Structure and Function in Primitive Society. New York: The Free Press, 1965.

Reynolds, David S. Beneath the American Renaissance: The Subversive Imagination in the Age of Emerson and Melville. New York: Alfred A. Knopf, 1988.

Rowe, John Carlos. At Emerson's Tomb: The Politics of Classic American Literature. New York: Columbia University Press, 1997.

---. Literary Culture and U.S. Imperialism. Oxford: Oxford University Press, 2000.

Said, Edward. Culture and Imperialism. London: Vintage, 1994.

Spiller, Robert E., gen. ed. Literary History of the United States. 3 Vols. New York: Macmillan, 1948.

Spiller, Robert E. "A Letter to American Literary Historians." Milestones in American Literary History. Westport, CT: Greenwood, 1977. 139-142.

Van Parijs, Philippe. Evolutionary Explanation in the Social Sciences: An Emerging Paradigm. Totowa, NJ: Rowman \& Littlefield, 1981. 